\title{
P230: The effect of health care-associated infections in the outcome of patients with heart failure
}

\author{
A Spyrou*, J Trikilis, C Panagiotou \\ From 2nd International Conference on Prevention and Infection Control (ICPIC 2013) \\ Geneva, Switzerland. 25-28 June 2013
}

\section{Introduction}

The patients hospitalized due to heart failure have higher percentage of contacting diseases and mortality rate when compared to other groups of patients, a fact that could be partially attributed to co-existing with health care-associated infections (HCAI).

\section{Objectives}

The purpose of the current study is the investigation of both the impact of HCAI on patients with heart failure and the correlation of the infection and the outcome of the disease.

\section{Methods}

70 patients with heart failure who were hospitalized in the Cardiological ICU of a Cardiological/Cardiosurgical Centre from January 2011 until December 2011 out of a total of 95 patients; the other 25 did not meet the specified criteria for their inclusion in the study. The HCAI were defined on the basis of the criteria of the US Centre for Disease Control (CDC). The statistics software Statistical Package for Social Sciences (SPSS) v 17 was utilized for the data analysis.

\section{Results}

$8.57 \%$ of the patients with heart failure presented an HSPA related infection. The patients who contacted the infection had a lengthier stay in the Cardiological ICU $(\mathrm{p}=0.04)$ and a lengthier overall hospitalization period $(p=0.04)$ when compared to the patients without infection. The mortality rate of the patients with infection was comparatively higher to that of the patients without infection ( $53 \%$ vs. $12 \%, \mathrm{p}<0.001)$.

\section{Conclusion}

The infections have a negative impact on the percentage of contacting diseases and mortality rate of patients hospitalized in the Cardiological ICU with heart failure. Further investigation of the correlation of HCAI and heart failure, as the development of knowledge in this specific sector can offer significant results in the therapeutic approach of these patients.

\section{Disclosure of interest}

None declared.

Published: 20 June 2013

\section{doi:10.1186/2047-2994-2-S1-P230}

Cite this article as: Spyrou et al:: P230: The effect of health careassociated infections in the outcome of patients with heart failure. Antimicrobial Resistance and Infection Control 2013 2(Suppl 1):P230.

Submit your next manuscript to BioMed Central and take full advantage of:

- Convenient online submission

- Thorough peer review

- No space constraints or color figure charges

- Immediate publication on acceptance

- Inclusion in PubMed, CAS, Scopus and Google Scholar

- Research which is freely available for redistribution 